\title{
Verskillende scenario's
}

\section{met die oog op privaat-kerkskool,}

staatsondersteunde en staatskool in 'n

veranderende onderwysbedeling

\author{
LJ S Steenkamp \\ Universiteit van Pretoria
}

Abstract

Models of education in the new South Africa: Private church schools or state-aided community schools?

The Nederduitsch Hervormde Church sees the basis of teaching and education to be a mother-tongue Christian education, culturally directed and of a high standard. Apart from the role of the Church, the state also has a responsibility towards the education of the child. This responsibility cannot be evaded. In the heterogeneous composition of the South African population, community schools are the obvious solution. The state-supported community school is cheaper than private or church schools, and at the same time it gives the state the attractive option of having the parents make a greater financial contribution to these schools. The statesupported community school, moreover, provides a world-wide recognized model, founded on healthy and accredited educational principles. Nevertheless, very necessary and unavoidable adaption to this model has seriously to be considered by the church, by means of the continued and supplementary education of teachers in their thoughts and their outlook on life. 


\section{INI FIDING}

Daar kan volgens verskeie aanduidings en uitsprake van politici en onderwysoelangegroepe aanvaar word dat staatskole en privaatskole steeds opsies in 'n nuwe onderwysbedeling sal uitmaak. Naas die genoemde twee modelle sal daar ook oorweging geskenk moet word aan die staatsondersteunde skool, aangesien 'n groot aantal skole tans volgens die model bedryf word en dit trouens ook 'n wêreld erkende onderwysmodel is. Naas die drie modelle is daar ook ander moontlikhede soos huisskole, satellietskole en afstandsonderrig. Dit is egter duidelik dat genoemde drie modelle in hoofsaak ter sprake sal wees onder ' $n$ nuwe bedeling. (Onderwysvernuwingstrategie 1992). Die Raad vir Opvoeding en Onderwys het tydens ' $n$ werksessie in Mei 1993 aandag aan hierdie sake gegee en die resultate in hierdie dokument vervat, oorweeg.

Met die drie onderwysmodelle voor oë, kan verskeie scenario's oorweeg word met die oog op verskillende moontlikhede en met inagneming van politieke, sosiale, ekonomiese en kerklike invloede wat 'n toekomstige onderwysstelsel kan beinvloed. Daar kan aanvaar word dat onderwys en opvoeding in die toekoms, selfs meer as in die verlede, die instrument sal word waardeur mense (kinders) se lewens- en wêreldbeskouing en waardes gevorm sal word (NEPI 1992:16). Om die rede is dit vir die kerk belangrik om indringend te besin oor die onderwys en alle opsies beskikbaar verantwoordelik te oorweeg met die oog op 'n aanvaarde, bekostigbare stelsel wat steeds 'n hoë mate van gehalte-onderwys in 'n nuwe konteks sal lewer.

Die Nederduitsch Hervormde Kerk van Afrika het in Artikel X.2 van sy Kerkwet 'n missie ten opsigte van opvoeding en onderwys geformuleer waarin hy mcdeverantwoordelikheid aanvaar vir die opvoeding en onderwys van die jeug van die hele volk in 'n Christelike-nasionale gees in huisgesin en skool (NHK A Kerkwet, Artikel X). Hierdie missie is bevestig met die Algemene Kerkvergadering van 1992 (NHKA Agenda, bl 223).

Om hierdie missie te bereik, behoort die volgende uitgangspunte nagestreef te word:

- Die kerk moet elke geleentheid aangryp om Christelike, volksgerigte en moedertaal-onderrig te behou en verder uit te bou in 'n toekomstige onderwysbedeling. Hierdie beginsels word wêreldwyd erken as opvoedkundig verstandig, aanvaarbaar en noodsaaklik met die oog op harmonie en orde in 'n heterogene konteks (Carpotorti 1979). Hierdie strategie moet nie in isolasie plaasvind nie, maar in samewerking met geidentifiseerde vennote wat dieselfde doelstellings nasteef, soos ander kerke, Christelike ouerverenigings, kultuurgroepe, en so meer. 
- Maksimale finansiële steun van staatsweë moet bepleit word, aangesien die onderrig en opleiding van die jeug seker die belangrikste bate van enige land is. Daar sal voorsiening gemaak moet word vir gevalle waar ouers die onderriggelde van hulle kinders nie kan bekostig nie (NHKA Notule 1992:145). Grootouers en ander familie sal ook waar moontlik hier verantwoordelikheid moet neem. Waar van toepassing, behoort belastingverligting toegestaan te word aan ouers wat substansiële bydraes maak ten opsigte van die onderrig van hulle kinders.

* Daar sal streng gewaak moet word teen die algemene verlaging van standaarde in 'n eenheidstelsel wat pariteit nastreef tussen alle groepe. Die beste effek met die oog op goeie onderwysvoorsiening lê ongetwyfeld in die handhawing van 'n hoë standaard binne die eise van 'n hoogs kompeterende wêreld. Ekonome is dit eens dat die ekonomiese groei van die land grootliks sal afhang van kwaliteit-onderwysvoorsiening vanaf primêre tot op tersiêre vlak (Onderwysvernuwingstrategie 1992).

- Die onderwys moet verder konsentreer op beroepsgerigte onderrig binne die milieu van Christelik- en kultuurgerigte onderwys om die kind so op te voed dat hy/sy aangepas kan wees in sy/haar sosiale-, leef-en werksomgewing. Die belyning van 'n toekomstige onderwysstelsel moet in lyn wees met 'n mannekrag. strategie en opleidingstrategie ter wille van die opheffing van alle leerders en die eventuele bereiking van die hoogste lewenskwaliteit vir al die inwoners van die land. Strategies is dit van groot belang dat beroepsinrigtings met tegniese gerigtheid dringend uitgebrei sal moet word. Waar daar tans ongeveer 350000 studente aan universiteite studeer en slegs 80000 aan tegniese kolleges, moet daarna gestreef word om hierdie omgekeerde driehoek reg te stel sodat daar teen die einde van die eeu 800000 studente tegniese onderrig kan ontvang.

- Daar moet gewaak word daarteen dat die uittreepunte uit die formele onderwys nie ontwrigtend op die kind inwerk nie. Die kerk, ouergemeenskappe en ander belangstellendes sal maniere moet bedink om kinders wat opleiding ontvang in die nie-formele sektor, te bedien met die noodsaaklike vorming ten opsigte van 'n algemene Christelike en besondere kulturele lewens- en wêreldopvatting.

- Daar sal ernstig besin moet word onr wyses waarop onderwysers en kinders bygestaan kan word om hulle Christelike waardes uit te leef te midde van 'n neutrale en selfs vyandige onderrigomgewing. 
* Die maksimale inspraak van die ouer in sake soos die bepaling van die etos van hulle skool, die aanstelling van personeel, die handhawing van standaarde, toelating tot gemeenskapskole, asook die identifisering, keuring en opleiding van onderwysers, moet sterk gepropageer word (NKHA AKV Agenda 1989:291).

* Die kerk moet hierdie uitgangspunte deur elke moontlike geleentheid verdedig, betuig en vestig in gesprekke met owerheidsinstansies, ringsrade, gemeentewerkgroepe vir onderwys en opvoeding, lidmate en by rolspelers by die onderhandeling van 'n toekomstige onderwysstelsel.

- In die bereiking van gestelde doelwitte moet die opleiding van onderwysers steeds plaasvind met inagneming van die missie van die kerk oor opvoeding en onderwys. Indien dit nie meer haalbaar is nie, sal alternatiewe metodes geimplementeer moet word ten einde die lewensbeskoulike by die onderwyser te versterk.

Vervolgens is dit noodsaaklik dat die kerk verskillende scenario's moet oorweeg ten opsigte van die staatskool, die staatondersteunde skool en die privaatskool. In hierdie oorwegings moet daar kennis geneem word van besluite van die kerk oor opvoeding en onderwys. Die kerk het hom in die verlede steeds uitgespreek teen privaat-kerkskole (groepskole), aangesien hy van oordeel was dat dit die onderwys fragmenteer en selfs kan lei tot allerlei afwyki.ıgs en tekortkomings as gevolg van die ontbrekende oorhoofse koördinering, bestuur en beheer. Die kerk het daarom telkens gekies vir die staatskool-opsie omdai die staat inderdaad verantwoordelik is vir die opleiding van sy burgers (NHKA Agenda 1967:125, Bylae X6, X31). 'n Voorwaarde wat die kerk in dié geval gestel het, was dat godsdiensvryheid eerbiedig moet word en dat die staat die beginsel van Christelike, volkseie (nasionale) en moedertaal-onderrig in die onderwysstelsel moet erken. In tye, soos na die Tweede Vryheidsoorlog, waar hierdie beginsels in gedrang gekom het, het die kerk as noodmaatreël Christelike privaat-(kerk) skole gesteun (CNO-skole). Die moontlikheid is daar dat 'n toekomstige onderwysopset hierdie beginsels weer in gedrang kan bring. Daarby kan voorsien word dat die moontlikheid van ' $n$ algemene verlaging van standaarde in 'n staatskool 'n wesenlike gevaar kan word met inagneming van al die faktore wat met die nastrewing van die pariteitsbeginsel gepaard gaan.

Die kerk sal verder moet aanvaar dat baie lidmate hulle kinders na staatskole sal stuur om verskillende redes (ekonomiese, politieke, ensovoorts), selfs al word daar privaatkerkskole op die been gebring. Die kerk sal teen die agtergrond van sy missie om al die kinders van die volk in 'n Christelike, volkseie en moedertaal gees te onderrig, ook voorsiening moet maak in sy strategie om diesulkes te bereik. Die 
moontlikheid moet oorweeg word dat die staatsondersteunde skool in die toekoms kan verdwyn en daar alleen 'n keuse gemaak sal kan word tussen 'n staatskool en 'n privaatskool. Die kerk sal egter alles in die stryd moet werp om die opsie van staatsondersteunde skole oop te hou, aangesien dit 'n meer bekostigbare moontlikheid vir ouers bied, met behoud van die gestelde beginsels. In hierdie opsig sal aanvaar moet word dat daar veranderings sal kom oor sake soos byvoorbeeld 'n persentasie oopstellings, groter bydrae van die ouers, en so meer. Die staat sal natuurlik ook baat by 'n staatsondersteunde opsie aangesien die ouer in hierdie geval 'n groter finansiële las (belasting) dra. In heterogene gebiede kan die staatsondersteunde skool egter ook probleme oplewer ten opsigte van gestelde uitgangspunte, aangesien die ouers wat hierdie beginsels onderskrywe, in die minderheid kan wees en die etos van die skool deur die meerderheid bepaal sal word. Tog kan selfs sulke moontlikhede gesien word as geleenthede met die oog op die positiewe bembloeding deur Christelike waardes. Alles in ag geneem, blyk dit noodsaaklik en verantwoordelik te wees om te beplan vir elke moontlike scenario en ouers en gemeentes dienooreenkomstig in te lig.

Afgesien van die bedreiginge wat 'n nuwe onderwysopset vir die gestelde beginsel van die kerk kan inhou, is daar uiteraard ook geleenthede wat die kerk sal moet aangryp om sy missie ten opsigte van opvoeding en onderwys te vervul.

\section{KOSTE VERBONDE AAN DIE STAATSONDERSTEUNDE EN PRIVAAT KERKSKOOL}

Navorsing deur die Sentrum vir Voortgesette Teologiese Toerusting (SVTT) van die Fakulteit Teologie (Afd A), Universiteit van Pretoria, het die volgende gegewens aan die lig gebring wat oorweeg kan word by die verskillende modelle. Twee staatsondersteunde hoërskole asook twee staatsondersteunde laerskole is in die ondersoek oorweeg uit 'n gemiddelde ekonomiese inkomstegroep, terwyl twee privaatkerkskole uit dieselfde inkomstegroep en omgewing se gegewens vergelyk is met die betrokke staatsondersteunde skole. Uit die ondersoek blyk sekere tendense wat rigtinggewend kan wees in die beplanning en oorweging van die beste opsies.

\subsection{Oprigtingskoste (1993)}

Sekondêre skool R 7.11 miljoen (750-1000 leerlinge)

Primêre skool R 5-7 miljoen (500-750 leerlinge)

Hierdie koste geld die oprigting van beide staatskole en staatsondersteunde skole. Uitbreidings en skepping van bykomstige fisiese geriewe kan egter baie goedkoper beding word by staatsondersteunde skole deur die bemiddeling en inisiatiewe van ouergemeenskappe. 


\subsection{Instandhoudingskoste}

Die instandhoudingskoste van sulke skole kan op een tot twee persent van die oprigtingskoste (volgens bourekenaarsformule) van so 'n skool gereken word. Dit sou beteken R50 000-R100 000 per jaar vir 'n laerskool en R100 000-R200 000 per jaar vir 'n hoërskool.

\subsection{Begrote inkomste benodig}

Die begroting van 'n staatskool sal uiteraard laag wees, aangesien die staat voorsiening maak vir die lopende bedryfskostes. By 'n staatsondersteunde en 'n privaatskool is dit egter 'n baie duurder onderne-ming, aangesien daar vir lopende uitgawes soos elektrisiteit, boeke, administrasie, en so meer voorsiening gemaak moet word.

\subsubsection{Primêre staatondersteunde skool (500 leerlinge - 1993)}

- Die staat dra tans ongeveer $87 \%$ by tot die bedryfskoste van die skool.

- Die ouergemeenskap dra tans ongeveer $13 \%$ by van die bedryfskoste van die skool.

- Inkomste benodig van ouers beloop tans R250 000-R300 000 per jaar (ongeveer R50 per kind per maand vir dic ouer).

\subsubsection{Primêre privaat-kerkskool (165 leerlinge-1993).}

Die inkounste van die skool word so saamgestel:

- Staatsubsidie $45 \%$ van die bedryfskoste van die skool.

- Skoolgemeenskap 55\% van die bedryfskoste van die skool.

- Plus donasies (minimaal).

Die skoolgemeenskap se $55 \%$ word weer so verdeel:

* Ouers is verantwoordelik vir $60 \%$ (van die 55\% wat die skoolgemeenskap bydra) van die bedryfskoste:

* eerste kind $\mathrm{R} 250$ per maand;

* twee kinders R 270 per maand;

* drie kinders (en meer) R290 per maand per kind.

- Lede van die skoolvereniging is verantwoordelik vir 40\% (van die $55 \%$ wat die skoolgemeenskap bydra).

* die Bestuur en elke lid van die skoolvereniging kom ooreen oor 'n bedrag wat hulle maandeliks betaal. Lede wissel van studente, grootouers, vriende. oud-leerlinge, en so meer. 
2.3.3 Sekondère staatsundersteunde skool (800-900 leerlinge-1993)

Inkomste benodig van ouers R500 000 - R600 000 ten opsigte van bedryfskoste (R65-R70 per kind per maand).

\subsubsection{Sekondère privaatskool (500-900 leerlinge)}

Sehondêre privaatskole se bydrae wissel tussen R375 en R1 000 per kind per maand, na gelang van die status van die skool en die onderriggeriewe wat dit bied (byvoorbeeld laboratoriums, sentrums, sportgeriewe, uitstappies, en so meer).

Indien voorsiening gemaak moet word vir die volle bekostiging van onderwysers deur die ouers (geen subsidie), sou dit by die primêre privaatskool 'n bykomstige bedrag van ongeveer $R 540$ 000-R 600000 kos - dus minstens 'n verdere R300 per maand per kind in 'n staatsondersteunde skool.

Die bestaande privaat-kerkskole werk op die beginsel waar die staat $45 \%$ bydra en die res $(55 \%)$ verdeel word tussen die ouers $(60 \%)$ en die skoolvereniging $(40 \%)$. Die skoolvereniging bestaan uit lede van die kerkgemeenskap (stemgeregtigdes) en ook buitelede wat die grondwet van die skool onderskryf (nie-stemgeregtigdes). In 'n nuwe bedeling kan die staatsubsidie selfs wegval.

Dit kan verder vermeld word dat ouers by die kerkskole sekere funksies van die skool oorneem soos finansies, administrasie, vervoer, en so meer. Daar word ook na-skoolse aktiwiteite aangebied, soos vaardighede in kookkuns, naaldwerk, kunsvlyt, ensovoorts, ten einde die kind vertroud te mak met sy leefwêreld en omgewing. Hierdie betrokkenheid bring natuurlik aansienlike besparings mee vir die betrokke skool. Die basiese kurrikulum word verder by die skole verryk en aangevul met sake wat die kerk se belydenis en lewe komplementeer. Trouens, die kategese-program vir die laerskoolkind word geintegreer met die skoolprogram, terwyl die amptelike kategeseleerplan eers begin by standerd 6 waar die kind na ' $n$ staatsondersteunde skool gaan en dus onder die invloedsfeer van die kerkskool uitbeweeg.

\section{DIE STAATSKOOI.}

\subsection{Eerste scenario}

'n Scenario wat aanvaar dat die staatskool 'n eie besondere etos openbaar is hoogs onwaarskynlik, omdat alle aanduidings daarop dui dat die betrokke skole heeltemal neutraal sal wees ten opsigte van godsdiens en kultuur. 


\subsection{Tweede scenario}

'n Scenario wat aanvaar dat die staatskool baie negatief sal verander ten opsigte van gestelde missie, sal deur die kerk negatief ervaar word. 'n Staatskool wat groepe na mekaar toe dwing, wat moedertaal-onderrig misken, neutrale onderrig voorskryf, maksimale staatinmenging bedryf en verlaging van standaarde tot gevolg kan hê, sal uiteraard negatief beoordeel word deur ouers en die kerk.

Daar moet egte: aanvaar word dat baie van ons lidmate se kinders wel so 'n skool sal bywoon om verskillende oorwegings.

\section{AANBEVELINGS:}

* In hierdie opsig lyk dit aangewese dat die kerk (gemeentes) 'n na-uurse onderrigmoontlikheid behoort te skep waar die lewensvorming van die kind aandag kan geniet.

- So 'n na-uurse kerkskool (informele onderwys) kan sekerlik ook aandag gee aan ander vakke wat uit 'n gerasionaliseerde kurrikulum kan verdwyn (bv Latyn, Bybelkunde, Geskiedenis, ensovoorts). So kan die basiese kurrikulum sinvol verryk word.

- Personeel vir so 'n na-uurse skool kan relatief goedkoop bekom word deur hulle op ' $n$ uurlikse basis te besoldig. Hier kan gedink word aan opgeleide onderwyseresse wat verkies om huisvroue te wees, of onderwysers wat uit diens gestel is.

* Waar die gemeentes nie oor lokale beskik nie, kan selfs van die huisskool-opsie gebruik gemaak word.

\section{DIE STAATSONDERSTEUNDE SKOOL}

\subsection{Eerste scenario}

'n Scenario waar die huidige opset van dié betrokke skool met betrekking tot die bepaling van die etos, moedertaal-onderrig en die handhawing van die Christelike karakter behou word, sal die kerk positief kan steun. Daar sal egter rekening gehou moet word met die feit dat selfs so 'n skool waarskynlik in beginsel oop sal moet wees, as mens 'n handves vir menseregte en ander uitsprake oor die saak in aanmerking neem. Die staat is steeds die grootste finansiële bydraer tot hierdie model en sal daarom sekere algemene beleidsbeginseis daarop wil toepas.

\section{AANBEVELINGS:}

- Hierdie skoolmodel wat tans sterk gemeenskapsbepaald is en 'n eie etos uitleef, hou uiteraard vir die kerk en die ouer goeie moontlikhede in. In hierdie geval sal die kerk moet kyk na moontlikhede om die behoeftige kind (ouer) by te staan deur: 
* fondse (plaaslik) in die lewe te roep;

* grootouers en ander wat dit kan bekostig aan te spoor om hulp te verleen;

* samewerking op plaaslike vlak met die ander kerke te sock ten einde gesamentlike doelstellings te koördineer.

\subsection{Tweede scenario}

In hierdie scenario word voorsien dat die staat drastiese veranderinge sal aanbring by die staatsondersteunde skool met betrekking tot toelating, verhoogde onderriggelde en voorskriftelikheid met betrekking tot die kurrikulum. So 'n opsie sou die gestelde missie van die kerk ingrypend raak, maar tog steeds 'n goedkoper opsie kan wees as die privaatskool.

\section{AANBEVELINGS:}

- Die kerk sal moet aanvaar dat daar van sy kinders is wat so 'n skool om verskeie redes sal bywoon. Daarom sal sy lidmate aangespoor moet word om in die hoogste mate betrokke te raak by die skool ten einde soveel moontlik geleenthede te benut om inspraak te bekom in die besluitnemingsproses van die skool. So kan daar in mindere of meerdere mate bepaal word watter onderwysers voor die kinders staan, watter gees die skool adem, en so meer. Hierdie opsie sal egter, gemeet aan die missie van die kerk oor onderwys en opvoeding, sekere probleme oplewer wat die ouer en die kerk se betrokkenheid by die opvoeding van die kind aansienlik sal moet verhoog.

\subsection{Derde scenario}

In hierdie scenario word voorsien dat die staatsondersteunde skool sal verdwyn en daar uiteindelik neł gekies sal kan word tussen 'n staatskooi of 'n privaat-kerkskool.

\section{AANBEVELINGS:}

- Die kerk sal hier weer eens moet rekening hou met die feit dat baie lidmate se kinders die staatskool sal bywoon. In hierdie geval verwys ons terug na die scenario's oor die staatskoolmodel.

- Die kerk sal aan die ander kant ook rekening moet hou met die feit dat daar kinders en ouers sal wees wat in so 'n geval eerder 'n privaat-kerkskool sou verkies, indien hulle dit kan bekostig.

- Die kerk sal dan moontlikhede moet oorweeg oor die oprigting, bedryf en instandhouding van 'n privaatskool met inagneming van die finansiële, fisiese en bedryfsimplikasies en vereiste kundighede wat betrekking het op sodanige skool. 
* Die kerk sal ook alternatiewe vorme vir so 'n privaat-kerkskool moet oorweeg. Hier dink mens aan satellietskole, huisskole en selfs aan 'n sentrum wat afstandsonderrig kan inisieer, studiemateriaal skep en kan koördineer tussen verskillende skole ten einde 'n deurlopende aanvaarde standaard daar te stel.

- Die SV'TT met sy binding aan die teologiese fakuiteit en die universiteit kan uitstekend aangewend word om as so 'n sentrum vir afstandsonderrig te dien (Hahn 1982:1). 'n Verdere voordeel wat so beding kan word, is om ook deur die SVTT aan sommige aspekte van die onderwyser se opleiding en verdere opleiding aandag te gee. Dit bly 'n onomstootlike feit dat die persoon en invloed van die onderwyser steeds een van die sentrale sake in die opvoedings-milieu is. Die noodsaaklike voortgesette navorsing oor onderwys en opvoeding en voortgesette opleiding is dan ook logies ingesluit in die opdrag van die SVTT (vgl Eklund 1961:10).

\section{DIE PRIVAAT-KERKSKOOL OPSIE}

\subsection{Die eerste scenario}

In hierdie scenario word voorsien dat die huidige reëling vir die oprigting en bedryf van 'n privaatskool gehandhaaf word. Dit sou beteken dat die staat $45 \%$ subsidie voorsien en dat ouers steeds die etos, standaard, aanstelling van onderwysers en dalk in ' $n$ groot mate die toelating tot die skool aan die hand van vasgestelde kriteria kan beheer. In hierdie geval sal sulke skole aan neergelegde vereistes moet voldoen soos deur die wet op privaatskole, wet 104 van 1986, voorgeskryf.

\section{AANBEVELINGS:}

* So 'n opsie sou deur die kerk ondersteun kon word, mits die eerste scenario by die staatskool en alternatiewelik die eerste scenario by die staatsondersteunde skool nie realiseer nie.

- Indien die tweede scenario by die staatskool werklikheid word en die staatsondersteunde skool heeltemal wegval, sal die kerk dringend moet besin oor die oprigting en bedryf van privaat-kerkskole. In so 'n geval sal al die implikasies van die privaat-kerkskool egter eers deeglik oorweeg moet word.

- Hierdie opsie sal baie duur wees, vanweë fisiese en ander geriewe wat dan deur die kerk en lidmate (ouers) voorsien sal moet word. Die totale instandhouding van so 'n skool met 'n onderwyserskorps sal na alle waarskynlikheid slegs deur die meer gegoede ouer bekostig kan word.

- Die probleem van fragmentasie van die onderwys kan hier vok ' $n$ wesenlike probleem word, aangesien sake soos standaarde nie oorhoofs gekontroleer en bestuur kan word nie. 
- Die finansiële implikasies kan in 'n mate verlig word as die gemeente oor fisiese geriewe soos kategeselokale beskik en as onderwysers (soos huisvroue wat gekwalifiseerd is) op 'n uurlikse basis benut kan word en as die staat voortgaan om $45 \%$ subsidie by te dra tot die bedryf van die privaatskool.

- Die feit dat die privaat-kerkskool uiteraard groot finansiële implikasies vir die ouers en gemeentes sal inhou, sal die kerk dwing om verskillende moontlikhede naas die privaat-kerkskool, soos na-uurse onderrig en bykomende afstandsonderrigmodelle te oorweeg, na gelang van plaaslike omstandighede.

- Die groter ouer- en kerklike betrokkenheid wat op hierdie wyse gegenereer word, sal uiteraard vir die gemeente en gemeenskapslewe tot voordeel wees. So 'n skool sal selfs kinders uit sy gemeenskap trek van buite die gemeente se geledere.

- Indien 'n gemeente oor die fisiese geriewe beskik en die nodige personeel kan bekom (party op uurlikse basis) en daar 'n noemenswaardige getal kinders betrek kan word, kan so'n skool na alle waarskynlikheid bedryf word met behoud van standaarde en sal dit deur 'n ouergemeenskap bekostig kan word. Die bekostiging van so 'n skool kan selfs makliker word indien ander geïdentifiseerde kerke sou saamwerk in so 'n onderneming. Die fisiese geriewe moet doelmatig wees om te kan registreer as 'n privaatskool.

- Waar daar nie oor die nodige infrastruktuur beskik word nie, kan ander vorme soos die huisskool en satellietskool oorweeg word met die veronderstelling dat dit aan wetlike vereistes moet voldoen.

- Daar moet aanvaar word dat so 'n privaat-kerkskool nog op primêre vlak (laerskool) bedryf en bekostig kan word, maar op sekondêre vlak (hoërskool) sal dit veel duurder wees om instand te hou. Daar moet sake in berekening gebring word soos sentrums, labo:atoriums en vakkeuses. Die belangrikste vorming vind plaas op die primêre vlak en 'n kind sal hom selfs in 'n redelike mate kan handhaaf op sekondêre vlak in 'n neutrale onderwysomgewing. Die feit dat die uittreepunt waarskynlik standerd 7 (vlak 9) kan wees, stel in die geval van sekondêre skole $r$.twe aanpassings en probleme waarmee die kerk ook sal moet rekening hou betreffende probleme wat die kind in sy adolessensie ervaar.

* 'n Ander voordeel van so 'n opsie sou wees om te oorweeg om elemente van die kategeseprogramme te integreer met die skoolprogram op die primêre vlak. Die dLalisme van 'n skoolprogram en 'n kerklike onderrigprogram kan op die wyse dalk opgevang word deur die opvoeding en onderwys van die kind in groter harmonie te laat gebeur. 
* In al bogenoemde gevalle kan die Sentrum vir Voortgesette Teologiese Toerusting dien om in sy gemeenskapsfunksie en as afstandsonderrigsentrum, dienste te lewer. Na-uurse onderrig waar die lewensbeskoulike aandag kry en selfs sekere skaars vakke (by skole) kan so 'n onderneming gehanteer word deur gemeentes of gemeenskappe met die bystand en leiding van die SVTT. Die SVTT kan saam met kundiges so 'n program fasiliteer en moniteer ten einde homogene standaarde van onderrig te verseker.

\subsection{Tweede scenario}

In hierdie scenario word uitgegaan van die aannames dat die privaatskool toegelaat sal word in ' $n$ nuwe bedeling, maar met groot verandering in die sin dat subsidies heeltemal wegval, en daar selfs sterk inspraak geeïs sal word deur die staat oor die sake wat die missie van die kerk oor opvoeding en onderwys in gedrang sal bring.

\section{AANBEVEI JNGS:}

- So 'n opsie sal selfs nog moeiliker bekostig kan word en na alle waarskynlikheid sal dit slegs toeganklik wees vir die ekonomies bevoorregtes.

- Sodanige opsie is slegs haalbaar indien die breër gemeenskap (bv grootouers en andere) 'n substansiële bydrae lewer tot die bedryf van die privaat-kerkskool.

- Indien bogenoemde realiseer, kan alle belangegroepe georganiseer word in 'n skoolvereniging saam met ouers wat die gestelde missie van die kerk onderskryf.

\section{ALGEMENL AANBEVELINGS}

- Die uitkoms van die beredenerilıs dui onteenseglik daarop dat die kerk en sy geformuleerde missie oor opvoeding en onderwys voor die keuse van verskillende opsies te staan gaan kom. Dit is verder moeilik om te voorsien watter opsie vir die kerk die mees aanvaarbare gaan wees, met inagneming van oorwegings soos kosteimplikasies, voorsienings van fisiese fasiliteite en onderwyspersoneel. Meer as een opsie is dus moontlik, afhangende van die plaaslike omstandighede, die finansiële drakrag van die gemeenskap en ander faktore. Die kerk sal sy Raad vir Opvoeding en Onderwys in staat moet stel om op 'n deurlopende wyse toerusting en inligting te voorsien in samewerking met die SVTT, met inagneming van elke besondere situasie (vgl Aucamp, Stander \& Van Graan 1986). Die keuses wat uitendelik uitgeoefen word, sal steeds realisties bekostigbaar en in die beste belang van die kind moet wees.

Wanneer die kerk se uitsprake en besluite in die verlede in ag geneem word, sou die eerste keuse uit verskillende moontlikhede die staatskool wees. Maar dan moet die staatskool so bedryf word dat Christelike volkseie en moe- 
dertaal-onderrig moontlik is. Onderwys kan met die model effektief bestuur en gekoördineer word en bekostigbaar wees vir alle kinders. Indien die staatskool hierdie beginsels egter ignoreer, sou die tweede moontlikheid, soos dit inderwaarheid tans plaasvind, die keuse vir die staatsondersteunde skool wees, waar Christelike volkseie moedertaalonderrig wel tot sy reg kan kom. Die moontlikheid moet egter ook voorsien word dat daar uiteindelik slegs twee modelle sal bestaan waaruit ouers kan kies, naamlik die staatskool en die privaatskool.

Dan word die privaatskool-opsie 'n wesenlike werklikheid, veral as die kerk en ouers die gestelde beginsels wil behou. Daar sal egter ook, soos voorgestel, gedink en beplan moet word vir die kinders wat om verskillende redes tog na die staatskool sal gaan of aan die omstandighede waar die privaat-kerkskool om spesifieke redes nie haalbaar is nie. Dit is hier waar die na-uurse skool by die kerk, of die huisskool, die satellietskool en die sentrum vir afstandsonderrig (gekoppel aan SVTT) dringend oorweeg sal moet word. Genoemde sentrum sal verder gebruik moet word vir bykomende opleiding en verdere opleiding van onderwysers. Hierdie laaste saak is uiteraard van wesenlike belang in 'n nuwe bedeling waar die opleiding van onderwysers waarskynlik aangepas sal word by nuwe politieke en ander eise en dit gevolglik 'n neutrale opleiding sal wees. Die invloed van die persoon van die onderwyser bly steeds van die allergrootste belang.

- In sy beplanning sal die Raad/SVTT aandag moet gee aan die ontwikkeling wat ook op die terrein van onderwysvoorsiening plaasvind (Kruger 1980:12-20). 'n Tipiese voorbeeld hiervan is die praktyk van afstandsonderrig wat deur die SVTT geïmplementeer en uitgebou kan word. Die voordeel hiervan is dat daar uit die sentrum koördinering en bestuur kan plaasvind met betrekking tot opvoedkundige en onderwysstandaarde, lewensbeskoulike elemente, ouerleiding en ander faktore wat in lyn is met die missie van die kerk. Dit lè binne dic universiteite se missie van gemeenskapsdiens en komplementeer terselfdertyd die beginsels wat die universiteit as opvoedings- en onderwysinstansie nastreef. Die SVTT sal sy infrastruktuur in so 'n geval moet uitbrei deur kundige lidmate op die onderwysgebied op 'n ad hoc basis te betrek, en ir. samewerking met die Raad vir Opvoeding en Onderwys programme en navorsing inisieer.

- Daar sal in die toerustingsprogramme van die SVTT ook indringende aandag gegee moet word aan ouerbegeleiding. Die ouer as primère opvoeder het in die verlede te maklik sy verantwoordelikhede ten opsigte van die opvoeding van sy kind na die skool toe oorgeskuif. Na-skoolse klasse asook aandklasse kan ingestel word en volwassenes kan verder toegerus word om toenemend ' $n$ kwaliteit lewe te kan lei en hulle kinders insgelyks op te voed. 
* Wanneer streeksowerhede realiseer en gesag na hulle afgewentel word in die vorm van oorspronklike gesag (herskikking van gesag), dan sou so 'n ontwikkeling se uitkomste positief gebruik kan word ten einde die missie van die kerk ten opsigte van opvoeding en onderwys op gemeenskapvlak te bevorder. In so 'n geval kan die moontlikhede waaruit die kerk sy keuses kan uitoefen, waarskynlik groter wees.

* Die verlaging van die uittreepunt tot vlak 9 (standerd 7) en die verdere voortgesette opleiding in die openbare sektor deur nie-formele onderwys, stel die kerk voor ' $n$ verdere probleem betreffende die opvoeding en vorming van die kind in 'n Christelik-volkseie milieu. Die instelling van 'n na-uurse skool by die kerk kan ook in hierdie geval as die oplossing van die probleem gesien word. Die kategeseprogram van die kerk sal ook hierdie saak moet hanteer.

- Die kerk sal verder dringend aandag moet gee aan die struktuur waarmee hy sy missie oor opvoeding en onderwys wil uitvoer. 'n Ondersoek deur die SVTT na die funksionering van die ringsrade en gemeentelike werkgroepe vir opvoeding en onderwys bevestig dat dit slegs in enkele gevalle goed funksioneer, en in die meeste gevalle dit slegs redelik of selfs glad nie funksioneer nie. Opsig oor intensiewe toerusting en gesamentlike beplanning met die onderskeie ringsrade en gemeentewerkgroepe is van wesenlike belang ten einde die regte strategie en besluite te neem op plaaslike vlak met die oog op 'n drasties veranderende onderwysopset. Daar sal ook adndag gegee moet word aan skakeling op die gemeentevlak met werkgroepe. Doeltreffende koördinering en gesamentlike beplanning kan die saak van Christelike volkseie moedertaal-onderrig net bevorder. Die Raad vir Opvoeding en Onderwys sal in samewerking met ringsrade en gemeentelike werkgroepe deurlopend aandag moet gee aan wyses waarop ouers en kinders gevorm kan word met die oog op die geloof van die lidmaat in Jesus Christus, die Heer van die kerk.

- In die uiteindelike beplanning moet daar besin word oor die finansiële implikasies, realistiese en haalbare moontlikhede en dan die beste belang van die kind oorweeg word met inagneming van die gegewe situasie.

\section{Literatuurverwysings}

African National Congress 1991. Discussion Paper for the ANC on Education Policy. Aucamp, J P, Stander, M W \& Van Graan, F 1986. Opleiding en organisasie ontwikkeling. Potchefstroom: Westvalia Boekhandel.

Boshoff, H 1991. Politieke verandering en waardeverskuiwings: Implikasies. Potchefstroom: Instituut vir toekomsstudies. 
Carpotorti, F 1979. Study on the rights of persons belonging tot ethnic, religious and linguistic minorities. New York: United Nations.

Departement van Onder en Kultuur, Administrasie Volksraad 1990. Die medeverantwoordelikheid en medeseggenskap van die georganiseerde ouergemeenskap in die gewone openbare skool. Pretoria: DOK.

Eklund, C R 1961. The alumni university: Education's new frontier. Adults Education 11/3, 161-171.

Hahn, W 1982. University education at the distance in West Germany: An example of significant progress. Continuum 47/1, 1-7.

Kruger, R A 1980. Beginsels en kriteria vir kumikulum ontwerp. Pretoria: HAUM.

Nederduitsch Hervormde Kerk van Afrika 1967, Agenda van die Algemene Kerkvengudering. Pretoria: NHKA.

Nederduitsch Hervormde Kerk van Afrika 1992a. Agenda van die Algemene Kerkvergadering. Pretoria: NHKA.

Nederduitsch Hervormde Kerk van Afrika 1992b. Kerkwet en Bepalings. Pretoria: NHKA.

[NEPI] The National Education policy investigation: The framework report summeries 1992. Cape Town: Oxford University Press.

Departement Nasionale Opvoeding 1992. Ondenwysvernuwingstrategie.

Van der Walt, J L; Dekker, E I \& Van der Walt, I D 1985. Die Opvoedingsgebeure: 'n Skrifmatige perspektief. Potchefstroom: PU vir CHO. 